\title{
Relation of Helicobacter pylori to the human gastric mucosa in chronic gastritis of the antrum
}

\author{
L L Thomsen, J B Gavin, C Tasman-Jones
}

\begin{abstract}
The spatial relations between bacteria and the affected tissues can indicate pathogenic mechanisms. This study was undertaken to define the spatial relation of Helicobacter pylori to the human gastric mucosa. Antibodies against gastric mucus and ruthenium red were used to stabilise the glycoprotein structure of the mucus and glycocalyces in antral biopsy specimens from eight patients infected with $H$ pylori. The location of organisms and ultrastructural features were assessed using systematic scanning and transmission electron microscopy: 92 (2)\% (mean (SE)) of $\boldsymbol{H}$ pylori were in the pit mucus, and 7 (3) $\%$ were in the surface mucus; $60(12) \%$ of $H$ pylori were close to epithelial cells, with only 5 (2)\% located near the epithelial intercellular junctions. Fine filamentous strands extended between organisms and nearby epithelial cells, with few organisms in membrane to membrane contact. $H$ pylori were not observed between, beneath, or within cells of the gastric mucosa. The preferred location of $H$ pylori in the gastric antrum is within the pit mucus close to the epithelial cell surface, with no evidence that they have a direct toxic effect on the mucosa.
\end{abstract}

Organisms have been observed in the gastric mucosa of humans since $1893^{\prime}$ but they excited little interest until 1983 when they were isolated by Warren and Marshall ${ }^{2}$ and subsequently named Helicobacter pylori. ${ }^{3}$ Although studies ${ }^{46}$ have shown a striking correlation between the presence of $H$ pylori and chronic gastritis, their role in its aetiology remains obscure. Neither a direct toxic effect nor a specific immunological reaction have yet been proved.

The spatial relations between bacteria and the affected tissues can indicate whether the pathogenic mechanisms are likely to be direct or indirect. ${ }^{7}$ For example, an intimate association with host cells affords advantage for toxinproducing organisms. ${ }^{8}$ The relation of $H$ pylori to the human gastric mucosa, however, has not been carefully studied.

A major difficulty in determining the in vivo location of bacteria in the gut is the collapse during preparation for histological examination of the highly hydrated mucus and the artifactual displacement of the organisms. ${ }^{910}$ Stabilisation of mucus with anti-mucus antibodies preserves the mucus layer in situ, ${ }^{9}$ however, and thus prevents misinterpretation of the relation of bacteria to the mucosa. ${ }^{10}$ Similarly, the glycocalyces at bacterial and epithelial cell surfaces, which also collapse during preparation for histological examination, may be preserved and shown by the use of ruthenium red" in the preparation of samples.

The research described in this paper used systematic microscopy to determine the relation of $H$ pylori to the gastric epithelium in infected human gastric biopsy specimens, in which the glycoprotein structure of the mucus and of the glycocalyces had been stabilised.

\section{Methods}

\section{SUBJECTS AND SAMPLES}

Biopsy specimens from the gastric antrum of eight subjects infected with $H$ pylori were studied. The subjects were selected from patients with dyspeptic symptoms attending the endoscopy clinic at Auckland Hospital. Only patients not receiving treatment for dyspeptic symptoms, who gave informed consent, and from whom the additional specimens could be obtained with reasonable comfort, were included in this study.

Three antral biopsy specimens (one for urease detection, one for histopathological assessment, and one for electron microscopy) were obtained from each subject from the region within $5 \mathrm{~cm}$ of the pyloric valve.

\section{UREASE DETECTION}

Urease activity in the biopsy specimens was determined using the urea broth test, ${ }^{12}$ and a colour change from orange to pink within 24 hours indicated a positive result.

\section{HISTOPATHOLOGICAL ASSESSMENT}

Biopsy specimens were immediately fixed in $4 \%$ neutral buffered formaldehyde. They were then routinely embedded in paraffin, and sectioned and stained with haematoxylin and $\operatorname{eosin}^{5}$ in the histopathology laboratory at Auckland Hospital. A histological diagnosis for each case was made by an experienced histopathologist and the chronic gastritis was graded according to the criteria of Whitehead et al,,$^{13}$ which are based on the numbers of inflammatory cells observed relative to the numbers of inflammatory cells present in histologically normal sections. The grades were: Normal=normal numbers of mononuclear cells and polymorphonuclear leucocytes. Mild=increased mononuclear cells and very occasional polymorphonuclear leucocytes. Moderate $=$ increased mononuclear cells and polymorphonuclear leucocytes. Severe $=$ markedly increased mononuclear cells and polymorphonuclear leucocytes, with intraepithelial polymorphonuclear leucocytes.

Additional sections were stained with the 
Giemsa stain ${ }^{14}$ and independently examined for the presence of Helicobacter-like organisms.

\section{ELECTRON MICROSCOPY}

The mucus layer was stabilised using a method similar to that described by Bollard et $a l^{9}$ for colon mucus. Antibodies were raised against gastric mucus obtained from a histologically normal human stomach at necropsy. ${ }^{15}$ The presence of antibodies to human gastric mucus in the rabbit serum was confirmed using an enzyme linked immunosorbent assay (ELISA) technique. An aliquot of a homogenate of gastric mucus in phosphate buffered saline (PBS) (1:9) was incubated in the wells of an ELISA plate (Nunc Intermed, Denmark) for 12-18 hours at $4^{\circ} \mathrm{C}$, followed by incubation with PBS containing $2 \%$ bovine serum albumin (Serva, Germany) and $2 \%$ gelatine for two hours at $20^{\circ} \mathrm{C}$. Next, the diluted rabbit serum was added and incubated for three hours at $20^{\circ} \mathrm{C}$, followed by the addition of horseradish peroxidase labelled goatantirabbit IgG (South Pacific Immunological Laboratories Ltd, New Zealand), and incubated for two hours at $20^{\circ} \mathrm{C}$. The plate was washed three times with PBS containing $0.05 \%$ tween 20 (Serva, Germany) between each incubation step. After the addition of O-phenyldiamine dihydrochloride (Sigma, USA), the absorbances of each well were read on an ELISA plate reader (EAR, SLT Labinst, Austria) at $486 \mathrm{~nm}$. The results from the serum of the immunised rabbit were expressed as a ratio to those from serum from a control rabbit. Complement activity was removed from the gastric mucus antiserum immediately before use by incubation at $56^{\circ} \mathrm{C}$ for 30 minutes.

Each biopsy specimen was carefully placed on

Figure 1: Diagram of a section through the gastric antral mucosa, showing the three regions $(S, P, G)$ of mucus examined for the presence of $\mathrm{H}$ pylori. $S=$ surface region of mucus, $P=$ pit region of mucus, $G=$ gland region of mucus, $L S=$ gastric luminal surface, $S E=$ surface epithelial cells, $S E=$ surface epithelial cells,
$P E=$ pit epithelial cells, $G E=$ glandular epithelium $L P=$ lamina propria.

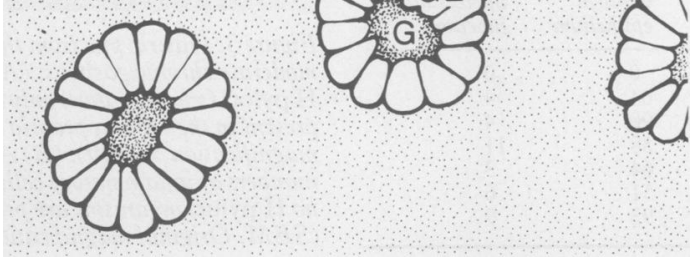

to dental wax, and the entire mucosal surface covered with undiluted rabbit antiserum for one hour at $4^{\circ} \mathrm{C}$.

The biopsy specimens were then prepared for electron microscopy using a method based on that described by Mackie et al. "They were fixed by immersion in a $0.5 \%$ glutaraldehyde solution containing $0.15 \%$ ruthenium red in $0.1 \mathrm{M}$ cacodylate buffer $(\mathrm{pH} \mathrm{7.4})$ for $30 \mathrm{~min}$ at $20^{\circ} \mathrm{C}$, then in $5 \%$ glutaraldehyde with $0.05 \%$ ruthenium red in the same buffer for $18-24$ hours at $4^{\circ} \mathrm{C}$. The biopsy specimens were washed in $0.05 \%$ ruthenium red in $0.1 \mathrm{M}$ cacodylate buffer at $\mathrm{pH}$ $7 \cdot 4$ (three rinses at 10 minute intervals), then postfixed for two hours in $0.66 \%$ osmium tetroxide in the same buffer containing $0 \cdot 1 \%$ ruthenium red. After washing a further three times ( 10 minute intervals) in $0.05 \%$ ruthenium red in $0.1 \mathrm{M}$ cacodylate buffer $(\mathrm{pH} 7 \cdot 4)$, they were dehydrated in increasing concentrations (10 minutes each step) of ethanol $(50,70,90$, $100 \%, 2 \mathrm{X}$ anhydrous) and two changes of propylene oxide (10 minutes each step). Next, they were placed in a propylene oxide:epoxy resin (EMBED-812, Electron Microscopy Sciences, Fort Washington, USA) (50:50) mixture for two hours, then transferred to a propylene oxide: epoxy resin (25:75) mixture for a further two hours, before being placed in $100 \%$ epoxy resin overnight under vacuum. Finally, they were embedded in flat molds and the resin cured overnight at $60^{\circ} \mathrm{C}$ under vacuum.

\section{SCANNING ELECTRON MICROSCOPY}

Samples were prepared for scanning electron microscopy using the method described by Thorne et al. ${ }^{16}$ Sections $2 \mu \mathrm{m}$ thick were cut from the resin blocks and examined, using a light microscope, for correct orientation before being mounted on pieces of carbon coated glass and stained with saturated uranium acetate ${ }^{17}(15 \mathrm{~min})$ and lead citrate ${ }^{18}(15 \mathrm{~min})$. After mounting on scanning electron microscopy stubs, the sections were examined using a back-scattered electron detector ${ }^{19}$ and an accelerating voltage of $30 \mathrm{kV}$ in an ISI DS-130 scanning electron microscope. ${ }^{16}$ The polarity of the image was reversed to give photomicrographs that resembled those obtained by transmission electron microscopy.

The numbers of $H$ pylor were counted within the mucus, which was divided into surface mucus, pit mucus, and gland mucus (Fig 1).

Within each region, the numbers of $H$ pylori organisms located close to the epithelial cell surface were noted. An organism was considered close to the epithelial cell surface when all or part of the organism was observed within the zone occupied by the microvilli on the surface of the epithelial cells. The numbers of $H$ pylori located within $1 \mu \mathrm{m}$ of the interepithelial cell junctions were also noted.

\section{TRANSMISSION ELECTRON MICROSCOPY}

Thin sections $(90 \mathrm{~nm})$, from selected areas of interest identified in the sections examined by back-scattered electron imaging, were cut on a Reichert ultramicrotome using glass or diamond knives. These were collected on copper grids, 


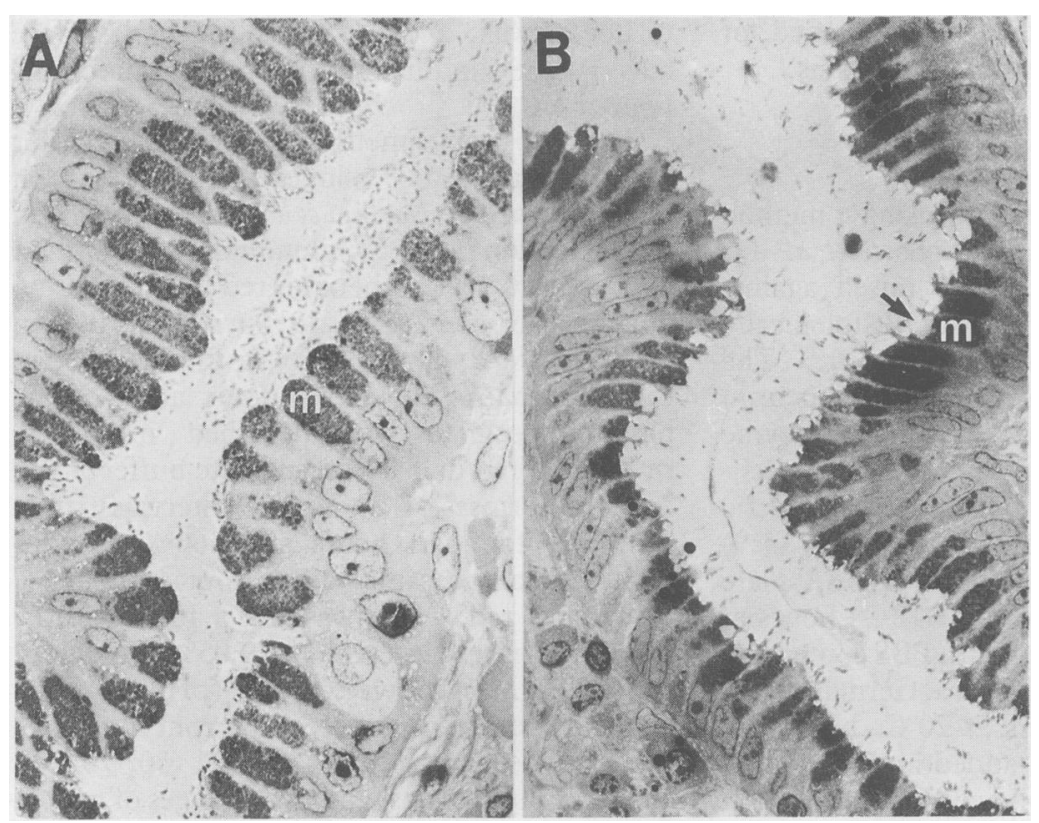

Figure 2: Gastric pits from the antrum of subjects with moderate chronic gastritis containing many $\mathrm{H}$ pylori. (A) Showing epithelial cells of normal appearance filled with mucus granules $(m)$. Some organisms are grouped together as in a colony. (Scanning electron microscope. Original magnification $\times 4200$ ). (B)

Showing epithelial cells with ragged surfaces (arrow) depleted of mucus granules (m). (SEM. Original magnification $\times 3800$ )

stained with uranium acetate ${ }^{17}$ and lead citrate, ${ }^{18}$ and examined at magnifications up to 140000 times with a Philips EM 410 LS transmission electron microscope operated at an accelerating voltage of $60 \mathrm{kV}$.

\section{Results}

All eight subjects had positive urea broth tests, and Helicobacter-like organisms were observed in Giemsa stained sections. Histopathological assessment showed that three subjects had mild, four had moderate, and one had severe chronic gastritis. Gastritis was noted as non-active - that is no polymorphonuclear leucocytes observed for one subject with mild chronic gastritis, and intestinal metaplasia was noted in one subject with moderate chronic gastritis.

\section{SCANNING ELECTRON MICROSCOPY}

The gastric mucus in all sections formed a complete layer over the epithelium and $H$ pylori were observed as moderately densely stained bodies within it (Fig 2). Organisms sectioned longitudinally were readily distinguished by their characteristically curved shape, but those in cross section were sometimes more difficult to identify positively. Organisms were observed in seven of the eight biopsy samples examined. The remaining one showed incomplete intestinal metaplasia. The organisms were unevenly distributed within each section (Fig 2A) and

Numbers and distribution of $\mathrm{H}$ pylori in biopsy specimens from seven patients

\begin{tabular}{|c|c|c|c|c|c|c|}
\hline \multirow[b]{2}{*}{$\begin{array}{l}\text { Grade of } \\
\text { gastritis }\end{array}$} & \multirow[b]{2}{*}{$\begin{array}{l}\text { Total no } \\
\text { observed }\end{array}$} & \multicolumn{5}{|c|}{ Location (\% of total) } \\
\hline & & $\begin{array}{l}\text { Surface } \\
\text { mucus }\end{array}$ & $\begin{array}{l}\text { Pit } \\
\text { mucus }\end{array}$ & $\begin{array}{l}\text { Gland } \\
\text { mucus }\end{array}$ & $\begin{array}{l}\text { Close to } \\
\text { epithelium }\end{array}$ & $\begin{array}{l}\text { Near } \\
\text { intercellular } \\
\text { junctions }\end{array}$ \\
\hline Mild & 19 & 0 & 100 & 0 & 0 & 0 \\
\hline Mild & 103 & 10 & 90 & 0 & 64 & 4 \\
\hline Mild & 550 & 14 & 86 & 0 & 90 & 4 \\
\hline Moderate & 111 & 10 & 90 & 0 & 58 & 11 \\
\hline Moderate & 280 & 5 & 95 & 0 & 64 & 3 \\
\hline Moderate & 1347 & 12 & 85 & 3 & 51 & 6 \\
\hline Severe & 67 & 0 & 100 & 0 & 93 & 9 \\
\hline
\end{tabular}

occasionally they were grouped as in a colony (Fig 2A).

The number of $H$ pylori in each section varied from 19-1347 (Table). Of the total number of $H$ pylori counted, 92 (2)\% (mean (SE)) were present in the mucus within the gastric pits and 7 (3)\% were in the surface mucus. Only in one subject, that with the greatest number of organisms, were organisms seen in the gland mucus, and these made up 3\% of the total (Table).

The proportion of $H$ pylori close to the epithelial cell surface was 60 (12)\% (Table). In six subjects, the proportion ranged from 51$93 \%$. In the remaining subject, in which the smallest number of organisms were observed, none were located close to the epithelial cell surface. In the subject in which organisms were seen in the gland mucus, $50 \%$ of these were close to the epithelial cell surface. Only 5 (1)\% of $H$ pylori were located near the epithelial intercellular junctions.

There was no apparent relation between the number and location of $H$ pylori organisms within any region of mucus and the appearance of the nearby epithelial cells. Large numbers of organisms were sometimes present in regions with epithelial cells of normal appearance, packed with mucus granules and with bulging cell surfaces (Fig 2A), as well as in regions in which the epithelial cells had ragged surfaces

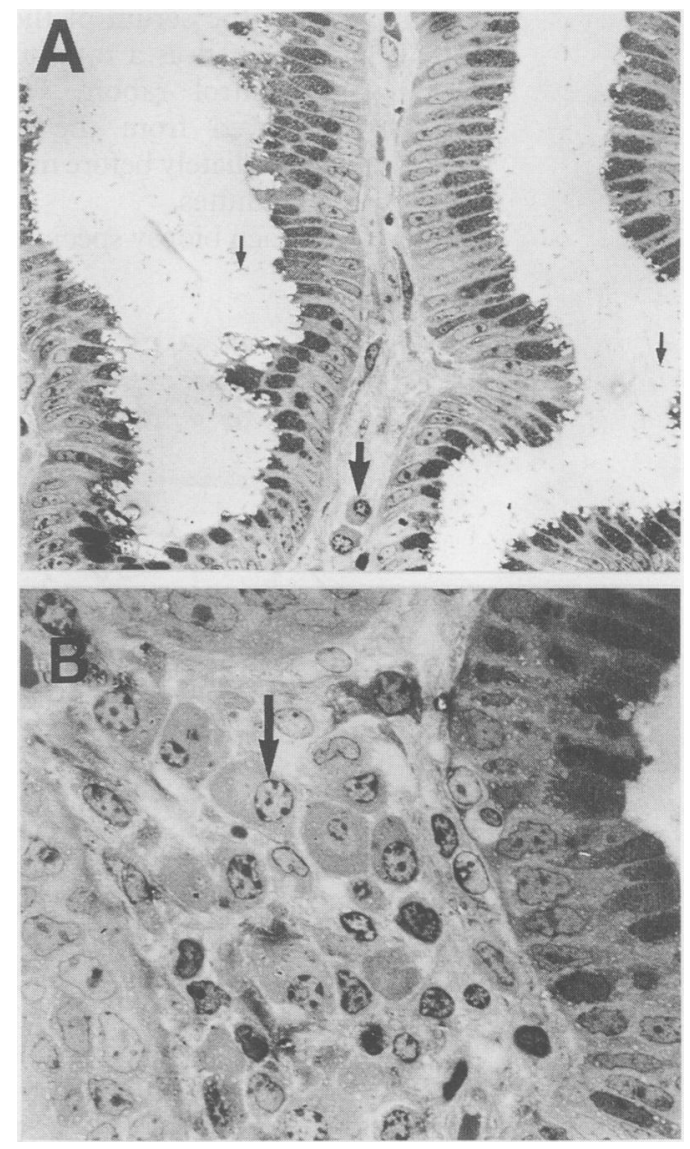

Figure 3: Gastric pits from the antral regions of subjects with moderate chronic gastritis. (A) Despite the presence of

$\mathbf{H}$ pylori (small arrows) only occasional inflammatory cells are present in the lamina propria (large arrow). (SEM. Original magnification $\times 2300$ ). (B) Although there are increased numbers of inflammatory cells (arrow) in the lamina propria, no $\mathrm{H}$ pylori organisms are present in the adjacent mucus. $(S E M$. Original magnification $\times 3100)$. 


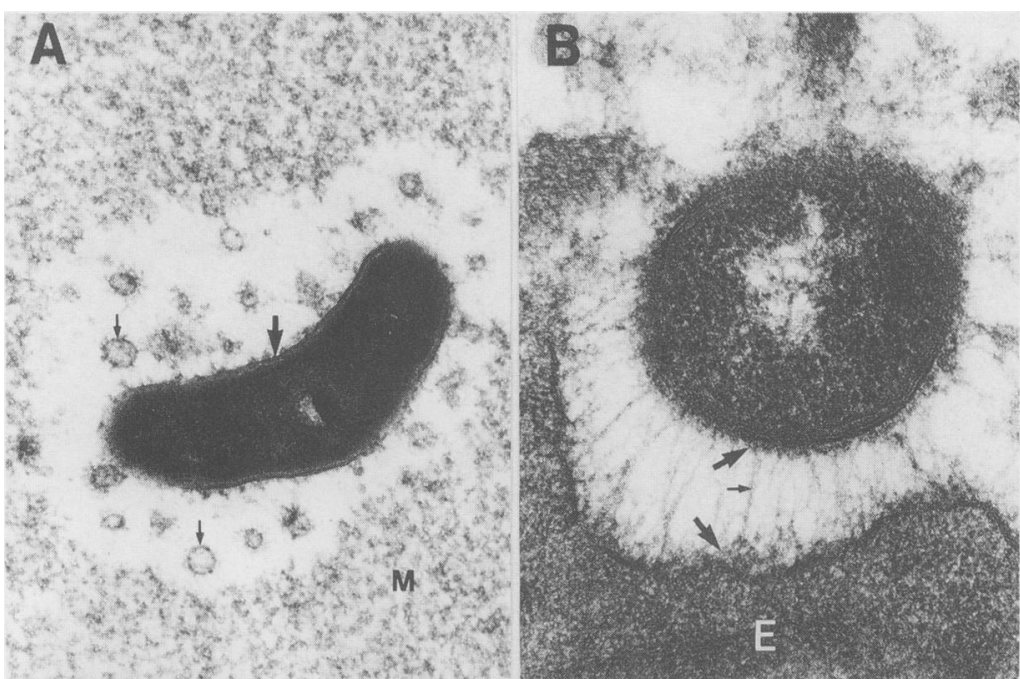

Figure 4: $\mathrm{H}$ pylori in the pit region of gastric antral mucosa from subjects with moderate chronic gastritis.

(A) An organism lying in the finely granular mucus $(M)$ but separated from it by a less granular zone containing glycocalyced bodies (smal glycocalyced bodies (small
arrows). The glycocalyx is a flocculent layer coating the limiting membrane (large arrow) of the organism.

(Transm

Transmission electron microscope. Original magnification $\times 40400)$. (B)

An organism close to and linked with an epithelial cell $(E)$ by radiating strands (small arrow) which link the glycocalyx (large arrows) of each of them. (TEM.

Original magnification $\times$ 57800 ).
(Fig 2B) or were depleted of mucus granules (Fig 2B).

There was no apparent relation between the number and location of $H$ pylori organisms within a region of mucus and the inflammatory cell infiltrate within the lamina propria beneath. Normal inflammatory cell numbers were sometimes observed in the lamina propria when large numbers of organisms were present in the adjacent mucus (Fig 3A), and conversely, dense inflammatory cell infiltration of the lamina propria was sometimes observed when no organisms were present in the adjacent mucus (Fig 3B).

There was no apparent relation between the number of $H$ pylori present and the histological grade of gastritis observed (Table).

\section{TRANSMISSION ELECTRON MICROSCOPY}

$H$ pylori organisms appeared as densely stained curved, oval, or circular bodies within the finely granular mucus (Fig 4A). The mucus surrounding some micro-organisms (Fig 4A) and that in the vicinity of the epithelial microvilli (Fig 5) appeared less granular than the remainder and in one subject it contained round, membrane bound, glycocalyceal bodies (Fig 4A). Organisms located close to epithelial cell surfaces often lay entirely within this electron-lucent zone (Fig 5).

Bacterial glycocalyx material was observed at the surface of all organisms (Fig 4A). Fine filamentous strands of glycocalyx-like material extended between the cell membranes of the organisms and between that of organisms and the nearby epithelial cells (Figs 4B, 6B). Many organisms lay close to epithelial cell membranes, but relatively few organisms were in membrane to membrane contact with epithelial cell surfaces (Figs 6A and B).

In some cases, however, where organisms lay close to or contiguous with epithelial cell surfaces, focal displacement and depletion of microvilli had occurred (Figs 5 and 6A). In only one instance was there any alteration within the epithelial cell immediately beneath the contact point with an organism (Fig 6B).

$H$ pylori organisms were never observed between, beneath, or within any cells of the gastric mucosa.

\section{Discussion}

This investigation has shown that the preferred location of $H$ pylori in the human gastric antrum is close to the surface of the epithelial cells lining the gastric pits, with no preference for the region close to intercellular junctions. Apart from some distortion and depletion of microvilli, there was no other evidence that the organisms had caused pathological changes in the mucosal epithelial cells, even when they were in membrane to membrane contact with each other.

This study seems to be the first systematic investigation of the relation of $H$ pylori to gastric epithelial cells and of their distribution in the gastric mucus. An essential feature of the investigation was the antibody stabilisation of the gastric mucus before tissue dehydration and preparation for electron microscopy. Bollard et $a l^{10}$ have clearly shown distinct differences in the location of micro-organisms in the colon, depending on the method of tissue preparation. When conventional methods were used the mucus layer collapsed during dehydration and organisms were observed within the crypts and close to, or in contact with, the epithelium. But, in all samples in which mucus was stabilised, the organisms were separated from the epithelium by a thick layer of mucus.

The present study also used scanning electron microscopy and back-scattered electron imaging, ${ }^{16}{ }^{19}$ which do not appear to have been used previously to study gastric mucosa. The scanning photomicrographs used in this study were produced using reversed polarity so that they resembled those produced by transmission electron microscopy. The use of back-scattered electrons to study resin sections through whole biopsy specimens was based on the techniques developed by Thorne $e t a l^{16}$ to study the cochlea. The method allows detailed study of large specimens without the loss of orientation associated with the small samples required for transmission electron microscopy, but the resolution obtained at higher magnifications (over $10000 \times$ ) is not as good because of the thickness $(2 \mu \mathrm{m})$ of the specimen and the method of image formation. The method enabled accurate counting of the number of organisms present rather than the semiquantitative estimation possible with light microscopy. ${ }^{12}$ In only two sections, in which there were large numbers of organisms clumped together, was it difficult to count individual micro-organisms.

That most organisms were located in the gastric pits (mean (SE) 92 (2)\%), and most (60 (12)\%) close to the epithelial cell surface suggests that their location was not random. It seems that the pit mucus offers some environmental advantages, perhaps protection to organisms from the 'bactericidal gastric juice. ${ }^{20}$

$H$ pylori are motile in a viscous environment, ${ }^{21}$ and thus the relatively few organisms observed in the surface mucus may represent those relocating from one gastric pit to another. Alternatively, they may have only recently penetrated the mucus from the luminal contents, and have been in the process of moving towards their preferred niche.

The tendency for $H$ pylori to lie close to the epithelial surface was not as marked, with $40 \%$ 
Figure 5: $\mathrm{H}$ pylori in the pit region in the gastric antral mucosa from a subject with moderate chronic gastritis.

The organisms lie close to the surfaces of epithelial cells in the vicinity of an

intercellular junction (curved arrow) in a zone which is less granular than the mucus above $(M)$. The epithelial cell membrane and mucus granules are intact but the microvilli (arrow) are displaced and reduced in number. (TEM. Original magnification $\times 40200$ ).

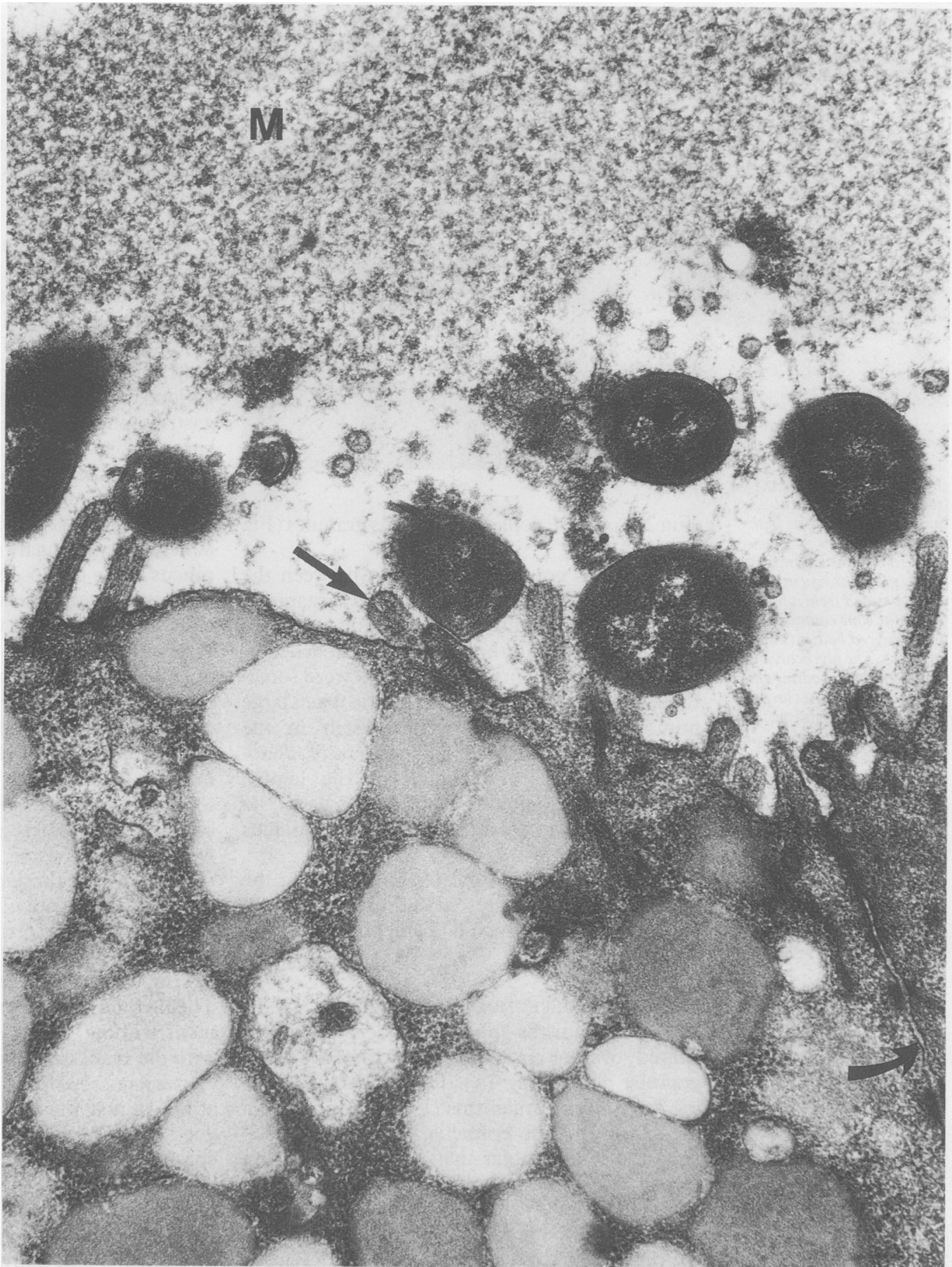

lying outside the zone of the microvilli. Although this latter group may also have included organisms relocating to their preferred site, their relatively high proportion and the fact that the few colonies of organisms which were observed also lay outside the zone of the microvilli argue against this. Nevertheless, the zone adjacent to the epithelial cell surface appears to be the preferred location of the majority of $H$ pylori.

Only $5 \%$ of organisms lay within $1 \mu \mathrm{m}$ of epithelial cell junctions, a proportion much lower than the $80 \%$ reported by Hazell et al, ${ }^{21}$ who counted micro-organisms within $2 \mu \mathrm{m}$ of the junctions. In the present material, gastric epithelial cells were up to $5 \mu \mathrm{m}$ in width so that a $2 \mu \mathrm{m}$ zone about each junction would encompass $80 \%$ of the entire cell surface.

Others $^{20}$ have also shown many $H$ pylori organisms, however, often arranged in groups, close to intercellular junctions, which may be paration ${ }^{10}$ as such groups were never observed in the stabilised mucus in the present study. Furthermore, those organisms with the closest association to epithelial cells, membrane to membrane contact, were never observed to impinge on interepithelial cell junctions. The claim $^{21}$ that $H$ pylori accumulate at the intercellular junctions to use nutrients available there was not supported by the present study.

Given the wide range in the numbers of organisms present, it was interesting that this had no apparent effect on the grade of chronic histological gastritis. This has also been indicated by others. ${ }^{22-25}$ Similarly, there was no correlation between the location of the organisms and either attributable to artefactual relocation during pre- 


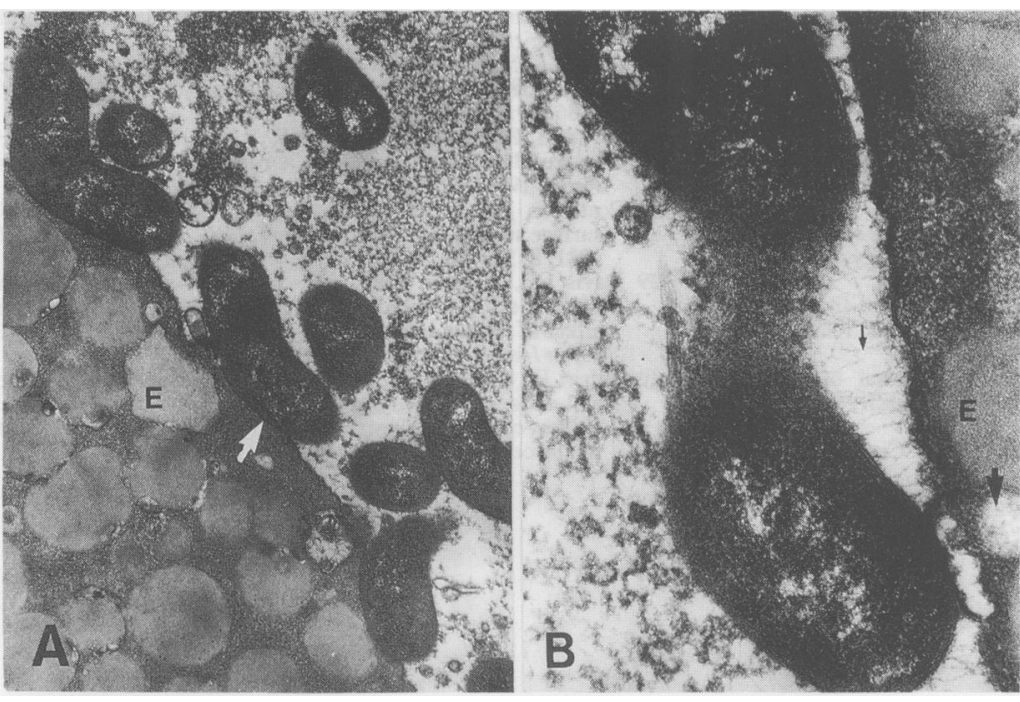

Figure 6: H pylori close to epithelial cells $(E)$ in the pit region of gastric antral mucosa from subjects with moderate chronic gastritis. (A) Organisms showing extensive apposition (arrow) of bacterial and cell membranes in a region devoid of microvilli. (TEM Original magnification $\times$ 19 100). (B) An organism showing glycocalyceal filaments (small arrow) and an intraepithelial vacuolation (large arrow) beneath a region of membrane to membrane apposition. (TEM. Original magnification $\times 58300)$. the morphology of adjacent epithelial cells or the degree of the subjacent inflammatory cell infiltrate. This suggests that the gastritis associated with $H$ pylori is not due to a direct cytopathic effect of the organisms on the mucosa.

A difficulty with studies of host/pathogen relations is that the time of initial infection often is not known. $H$ pylori infection does not always produce symptoms, ${ }^{6}$ and thus the patient may not present for endoscopic investigation for some time. It is also possible that the nature of the host/pathogen relation changes with time. The present study may have included subjects at different phases of the disease. For one subject, however, the time of infection has been accurately defined, ${ }^{4}$ and a biopsy specimen was obtained two years after self inoculation and included in the present study. This sample showed severe chronic histological gastritis but very few organisms present, suggesting that once established the disease may require only minimal numbers of organisms to persist.

All those biopsy specimens which showed $H$ pylori, also contained mixed inflammatory cell infiltrates in the lamina propria, although, here again, there was no clear quantitative relation between those factors. While the presence of plasma cells and lymphocytes in all cases is consistent with an immunological response to the organisms, ${ }^{26} 27$ it seems that such a response is largely inappropriate or ineffective against $H$ pylori organisms in the gastric mucosa.

The strand like material observed connecting the glycocalyces of $H$ pylori with each other and with epithelial cells may have developed because of attractive forces between the glycocalyx material at these two surfaces. ${ }^{28}$ They are believed to be involved in adherence between bacteria and epithelial cell surfaces. ${ }^{82829}$ While the ruthenium red used in the preparation of samples would have enhanced visualisation of these connections, other forms of connection such as pili may not have been resolved..$^{28}$

Bode $e t a l^{20}$ suggested that, after initial location close to an epithelial cell surface, the adhesion of $H$ pylori to the apical membrane is the final step in the process of association with the mucosa. Furthermore, Zafriri et $a l^{30}$ have postulated that in general, adhesion of bacteria to cells directs the diffusion of toxins, and enhances the pathogenic activity of the organisms.

Bode et $a l^{20}$ also believe that adhesion of $H$ pylori is followed by subcellular alterations to the affected epithelial cells, including depletion of microvilli, dissolution of mucous granules resulting in translucent empty structures, and increased generation of sialic acid-rich glycoproteins. Observations in the present study do not support such direct bacterial action. Relatively few organisms were observed lying very close to cell surfaces, and such epithelial cells appeared unaltered apart from displacement or depletion of some microvilli. The reasons why a few bacteria develop such a close association with epithelial cells remain obscure.

The present study indicates that virtual membrane-to-membrane contact, accumulation at intercellular junctions, and incorporation into epithelial cells or the lamina propria are not important features of the pathogenic action of $H$ pylori. It seems likely that physicochemical alterations in the protective gastric mucus layer may be more important. ${ }^{15}$

This research was supported by the Ruth Spencer Medical Research Fellowship Trust.

We would like to acknowledge the assistance of Dr I Hamilton, Dr M Miller, Dr J McKay, Mr M A Vanderwee; Mr A Ellis for assistance with preparation of Figure 1; and Mrs K Siow for typing the manuscript.

1 Bizzozero G. Ueber die schaulchformigen drusen des magendarmkanals und die bezienhungen ihres epithels zu dem oberflachenepithel der schleimhaut. Arch F Mikr Anast 1893; 42: 82 .

2 Warren JR, Marshall B. Unidentified curved bacilli on gastric epithelium in active chronic gastritis. Lancet 1983; i: 1273-5.

3 Marshall BJ, Goodwin CS. Revised nomenclature of Campylobacter pyloridis. Int $\dot{f}$ Systematic Bacteriol 1987; 37: 68.

4 Morris A, Nicholson G. Ingestion of Campylobacter pyloridis causes gastritis and a raised fasting gastric pH. Am $\mathcal{J}$ Gastroenterol 1987; 82: 192-9.

5 Morris A, Maher K, Thomsen L, Miller M, Nicholson G, Tasman-Jones C. Distribution of Campylobacter pylori in the human stomach obtained at postmortem. Scand $\mathcal{F}$ Gastroenterol 1988; 23: 257-64.

6 Blaser MJ. Gastric Campylobacter-like organisms, gastritis, and peptic ulcer disease. Gastroenterology 1987; 93: 371-83.

7 Freter R. Mechanisms of association of bacteria with mucosal surfaces. In: Adhesion and microorganism pathogenicity. (Ciba Foundation Symposium 80.) Tunbridge Wells: Pitman Medical, 1981: 36-55.

8 Beachey EH. Bacterial adherence: adhesin-receptor interactions mediating the attachment of bacteria to mucosal tions mediating the attachment of bacte
surfaces. F Intern Dis 1981; 143: 325-45.

9 Bollard JE, Vanderwee MA, Smith GW, Tasman-Jones C Gavin JB, Lee SP. Preservation of mucus in situ in the rat Gavin JB, Lee SP. Preservation of muc

10 Bollard JE, Vanderwee MA, Smith GW, Tasman-Jones C Gavin JB, Lee SP. Location of bacteria in the mid-colon of the rat. Appl Environ Microbiol 1986; 51: 604-8

11 Mackie EB, Brown KN, Lam J, Costerton JW. Morphologica stabilization of capsules of group B streptococci, types Ia, Ib II, and III, with specific antibody. $\mathcal{F}$ Bacteriol 1979; 138 : 609-17.

12 Hazell SL, Borody TJ, Gal A, Lee A. Campylobacter pyloridis gastritis. I: Detection of urease as a marker of bacterial colonization. Am $\mathcal{F}$ Gastroenterol 1987; 82: 292-6.

13 Whitehead R, Truelove SC, Gear MWL. The histologica diagnosis of chronic gastritis in fibreoptic gastroscope biopsy specimens. F Clin Pathol 1972; 25: 1-11.

14 Gray SF, Wyatt JI, Rathbone BJ. Simplified techniques for identifying Campylobacter pyloridis. $\mathcal{F}$ Clin Pathol 1986; 39. 1279.

15 Thomsen L, Tasman-Jones C, Morris A, Wiggins P, Lee S Forlong C. Ammonia produced by Campylobacter pylori neutralises $\mathrm{H}^{*}$ moving through gastric mucus. Scand Gastroenterol 1989; 24: 761-8.

16 Thorne PR, Vujcich TE, Gavin JB. Back-scattered electron imaging of sections through the cochlea: a new technique for studying cochlear morphology. Stain Technol 1987; 62: 191-9.

17 Watson ML. Staining of tissue sections for electron microscopy with heavy metals. $\mathcal{F}$ Biophys Biochem Cytol 1958; 4 475-8.

18 Sato T. A modified method for lead staining of thin sections. f Electron Microsc 1967; 16: 133.

19 Robinson VNE. Imaging with backscattered electrons in scanning electron microscope. Scanning 1980; 3: 15-26. 
20 Bode G, Malfertheiner P, Ditschuneit H. Pathogenic implications of ultrastructural findings in Campylobactor pylor related gastroduodenal disease. Scand $\mathcal{F}$ Gastroenterol 1988 ; 23 (suppl 142): 25-39.

21 Hazell SL, Lee A, Brady L, Hennessy W. Campylobacter pyloridis and gastritis: association with intercellular spaces and adaptation to an environment of mucus as important factors in colonization of the gastric epithelium. $\mathcal{F}$ Infect Dis 1986; 153: 658-63.

22 Price AB, Levi J, Dolby JM, et al. Campylobacter pyloridis in peptic ulcer disease: microbiology, pathology, and scanning peptic ulcer disease: microbiology, pathology, and scanning

23 Johnston BJ, Reed PI, Ali MH. Campylobacter-like organisms in duodenal and antral endoscopic biopsies: relationship to inflammation. Gut 1986; 27: 1132-7.

24 Rollason TP, Stone J, Rhodes JM. Spiral organisms in endoscopic biopsies of the human stomach. $\mathcal{F}$ Clin Patho $1984 ; 37: 23-6$.

25 Jones DM, Lessells AM, Eldridge J. Campvlobacter-like organisms on the gastric mucosa: culture, histological, and serological studies. F Clin Pathol 1984; 37: 1002-6.

26 Morris A, Nicholson G, Lloyd G, Haines D, Rogers A, Taylo D. Seroepidemiology of Campylobacter pyloridis. NZ Med $\mathcal{F}$ 1986; 99: 657-9.

27 Wyatt JI, Rathbone BJ, Heatley RV. Local immune response to gastric campylobacter in non-ulcer dyspepsia. $\mathcal{f}$ Clin Pathol 1986; 39: 863-70.

28 Costerton JW, Irvin RT, Cheng K-J. The role of bacteria surface structures in pathogenesis. CRC Crit Rev Microbio 1981; 8: 303-38.

29 Davis CP, Avots-Avotins AE, Fader RC. Evidence for bladder cell glycolipid receptor for Escherichia coli and the effect of neuraminic acid and colominic acid on adherence. Infect Immun 1981; 34: 944-8.

30 Zafriri D, Oron Y, Eisenstein BI, Ofek I. Growth advantage and enhanced toxicity of Escherichia coli adherent to tissue and enhanced toxicity of Escherichia coli adherent to tissue by the cells. $\mathcal{F}$ Clin Invest 1987; 79: 1210-6. 